\title{
Maahanmuuttajaopiskelijoiden sosiaalipedagoginen ohjaus vapaassa sivistystyössä
}

\author{
Elina Nivala
}

oulukuussa 2020 päättyy hanke, jossa on kehitetty sosiaalipedagogisen
viitekehyksen pohjalta maahanmuuttajien parissa tehtävää ohjaustyötä vapaassa sivistystyössä. Sosiaalipedagoginen ohjaus vapaan sivistystyön oppilaitoksissa - kohti osallisuutta ja merkityksellistä elämää (SOSPEVA) -hanketta hallinnoi Suomen kansanopistoyhdistys ry. Yhteistyökumppaneina ovat olleet Itä-Suomen yliopisto, Bildningsalliansen rf ja Opintokeskukset ry. Hanketta on rahoittanut Opetushallitus.

Hankkeen työskentely alkoi marraskuussa 2018 aloitusseminaarilla, jossa käynnistettiin yhteistoiminnallinen prosessi maahanmuuttajaopiskelijoiden ohjauksen kehittämiseksi kolmessa teemaryhmässä. Teemaryhmät muodostettiin kolmen painopisteen ympärille: ohjausosaaminen ja henkilökohtaistaminen, sosiaalinen integraatio sekä jatkopolut. Yhteinen työskentely jatkui keväällä ja syksyllä 2019 kaikille yhteisissä työpajatapaamisissa sekä tapaamisten välillä teemaryhmien kokoontumisissa. Työskentelyssä muodostettiin erilaisten vaiheiden kautta yhteistä käsitystä siitä, millaista maahanmuuttajaopiskelijoiden sosiaalipedagoginen oh- 
jaus vapaan sivistystyön kentällä voisi olla. Tämä käsitys rakentui toisaalta vapaan sivistystyön oppilaitoksissa toteutettavan ohjauksen periaatteiden, tavoitteiden ja työmuotojen tunnistamisen ja toisaalta sosiaalipedagogiseen ajatteluun tutustumisen kautta niin, että nämä kaksi näkökulmaa yhdistyivät vähitellen jaetuksi ymmärrykseksi ohjauksen tavoitetilasta. Hankkeessa luotua uudenlaista sosiaalipedagogisen ohjauksen mallia pilotoitiin kuudessa kansanopistossa ja kuudessa opintokeskuksessa lokakuun 2019 ja maaliskuun 2020 välisenä aikana. Pilotointiraporttien ja pilotointien aikana toteutettujen opiskelija- ja työntekijähaastattelujen pohjalta mallia muokattiin ja sen kuvausta tarkennettiin. Mallista työstettiin Peda.net-sivusto (Sosiaalipedagogisen ohjauksen malli 2020), joka sisältää mallin kuvauksen, taustamateriaaleja ja lisätietovinkkejä.

Sosiaalipedagogisen ohjauksen malli perustuu vapaan sivistystyön perinteen ja sosiaalipedagogisen ajattelun yhdistämiseen. Sosiaalipedagogiikka on hyvin moninainen tieteenala ja käytännön työala, mutta käytäntöjen kehittämiseen tähtäävässä keskustelussa on tavanomaista viitata aivan tietynlaiseen ajattelu- ja työtapaan sosiaalipedagogisena. Tähän työtapaan liitetään muun muassa tavoitteet tasavertaisten ja kunnioittavien kohtaamisten mahdollistamisesta, yhteisöllisyyden vahvistamisesta, jokaisen ihmisen osallistumisen ja toimijuuden tukemisesta, luovan toiminnan mahdollisuuksien hyödyntämisestä sekä toiminnan reflektoimisesta suhteessa teoreettiseen ymmärrykseen. (Ks. esim. Nivala \& Ryynänen 2019.) Nämä piirteet näkyvät selvästi myös sosiaalipedagogisen ohjauksen mallissa. Se on ajattelun ja toiminnan kehys, jota maahanmuuttajaopiskelijoiden parissa työskentelevä ohjaaja voi hyödyntää toimintansa kehittämisessä. Mallia voi soveltaa erilaisissa tilanteissa olevien opiskelijoiden kanssa ja eri koulutusmuodoissa. Kyseessä ei ole tiukasti määritelty ohjauksen prosessikaavio, jota tulee toteuttaa sellaisenaan. Sen sijaan tärkeää on omaksua mallin perusajatukset ja soveltaa niitä mielekkäillä tavoilla eri tilanteissa.

Sosiaalipedagogisen ohjauksen mallissa on kolme osa-aluetta: 1) ohjauksen periaatteet, 2) ohjauksen prosessi ja 3) työmenetelmät. Ohjauksen periaatteet ohjaavat kaikkea toimintaa, kuten sitä, millaisen suhteen ohjaaja pyrkii rakentamaan opiskelijaan ja millaisella otteella hän ohjaustyötä tekee. Periaatteita määriteltiin yhteisessä prosessissa yhteensä viisi. Ensimmäinen periaate on kohtaaminen. Ohjaajan tulee kohdata opiskelija ainutlaatuisena, arvokkaana ja kokonaisena ihmisenä. Kohtaaminen perustuu haluun ymmärtää opiskelijaa, tutustua häneen ja kuulla sekä hä- 
nen menneisyydestään että tulevaisuuden toiveistaan. Kohtaamisen perustana on pyrkimys dialogiin, jonka lähtökohtana on tasavertaisuus ihmisinä, molemminpuolinen hyväksyntä, kunnioitus ja arvostus. Dialogi on molemminpuolista todellisuuksien jakamista, joka edellyttää avoimuutta ja luottamusta, läsnäoloa ja aikaa.

Ohjauksen toinen periaate on toivo, tulevaisuususko ja rohkeus. Ohjaajan tehtävänä on tukea opiskelijaa näkemään mahdollisuuksiaan ja tunnistamaan toiveitaan. Tähän tarvitaan toivon luomista ja ylläpitämistä sekä uskoa opiskelijan mahdollisuuksiin mielekkääseen elämään suomalaisessa yhteiskunnassa. Toivon ja uskon luominen edellyttää sitä, että ohjaaja arvioi yhdessä opiskelijan kanssa tämän tilannetta, jotta he voivat tunnistaa opiskelijan mahdollisuuksia realistisesti. Toivo on perusta opiskelijan toimintakyvylle, tulevaisuususkolle ja rohkeudelle toimia omassa elämässään.

Ohjauksen kolmas periaate on aktiivisuus ja toimijuus. Koko ohjaussuhde pohjautuu siihen, että ohjaaja näkee opiskelijan oman elämänsä asiantuntijana. Ohjauksen kautta hän tukee opiskelijaa itse ymmärtämään omaa asiantuntijuuttaan ja toimimaan aktiivisesti eri tilanteissa. Kyse on opiskelijan toimijuuden tukemisesta esimerkiksi yhdessä tekemisen ja pohtimisen, valintojen ja päätösten äärelle pysähtymisen ja niihin vaikuttavien asioiden selvittämisen, tiedonhankinnassa auttamisen, erilaisiin toimintaympäristöihin tutustumisen ja toimintamahdollisuuksien tarkastelun kautta. Tavoitteena on, että opiskelija kasvaa kohti oman elämänsä toimijuutta.

Ohjauksen neljäs periaate on yhteisöllisyys ja kokonaisvaltaisuus. Ohjaus nähdään vapaan sivistystyön oppilaitoksissa koko yhteisön asiaksi. Ohjaajana toimivat tarvittaessa kaikki työntekijät kohdatessaan tilanteita, joissa opiskelija kaipaa apua tai asioiden yhteistä pohdintaa. Myös vertaisohjaus on tärkeää ja sille järjestetään mahdollisuuksia. Ohjaus ymmärretään siis sekä muodollisena nimetyn ohjaajan ja opiskelijan välisenä prosessina että epämuodollisena koko elämää ja yhteisöä koskevana tukemisena. Yhteisöllisyys ohjauksen periaatteena tarkoittaa myös sitä, että oppilaitoksissa pyritään vahvistamaan opiskelijoiden yhteenkuuluvuuden tunnetta. Ohjauksen tavoitteena on kaksisuuntainen kotoutuminen eli yksinkertaistaen se, että myös yhteisö oppii uutta, kun sinne tulee uusia jäseniä. Lisäksi ohjaus on kokonaisvaltaista siinä mielessä, että opiskelija nähdään kokonaisena ihmisenä, ei ainoastaan opiskelijana tai tulevana työntekijänä. Siten ohjaaja on valmis tukemaan opiskelijaa tarvittaessa kaikilla elä- 
mänalueilla. Hänen ei tarvitse kuitenkaan osata kaikkea, vaan tarvittaessa hän ohjaa opiskelijan muiden palveluiden piiriin.

Ohjauksen viides periaate on mahdollisuuksien tunteminen ja tunnistaminen. Maahanmuuttajaopiskelijoiden kanssa työskentelevän ohjaajan on tärkeää tuntea laajasti erilaisia jatkopolkumahdollisuuksia sekä koulutuksen, työelämän että muun toiminnan kuten vapaaehtoistyön ja kansalaistoiminnan alueilla. Hänellä tulee olla myös aikaa selvittää asioita yhdessä opiskelijan kanssa. Tavoitteena on yhteisessä prosessissa tunnistaa opiskelijalle mielekkäimmät mahdolliset jatkopolut.

Sosiaalipedagogisen ohjauksen mallin toinen osa-alue on ohjauksen prosessin jäsennys. Ohjaus ymmärretään pitkäkestoisena prosessina, josta voidaan tunnistaa erilaisia vaiheita. Niiden ymmärretään toteutuvan limittäin niin, että ne ovat kaikki jossain määrin läsnä koko ohjausprosessin ajan. Ohjauksen prosessin vaiheiden jäsennyksessä on hyödynnetty "myönteisen tunnistamisen" toimintatapaa, joka on kehitetty nuorisotyön ammattilaisten ja tutkijoiden yhteistyönä (ks. Häkli, Kallio \& Korkiamäki 2015; Korkiamäki, Kallio \& Häkli 2016). Myönteisen tunnistamisen teoreettisena perustana ovat niin sanotut tunnustamisen teoriat, joissa korostetaan ihmisen hyvinvoinnin lähtökohtana muilta ihmisiltä saatua tunnustusta itselle merkityksellisistä asioista. Ohjausprosessin vaiheet ovat 1) tutustuminen, 2) tunnustaminen ja 3) tukeminen.

Tutustuminen on luonnollista ohjauksen alkuvaiheessa, mutta se jatkuu ja syvenee koko prosessin ajan. Tutustuminen edellyttää kohtaamista, opiskelijan näkemistä avoimesti ainutlaatuisena ihmisenä. Tärkeää on läsnäolo, kuunteleminen ja kertomaan rohkaiseminen, maahanmuuttajaopiskelijoihin tutustumisessa erityisesti elämäntarinan kuuleminen. Todellinen tutustuminen edellyttää luottamuksen rakentamista. Tutustumiseen perustuu se, että ohjaaja pystyy yhdessä opiskelijan kanssa tunnistamaan tämän osaamista, tavoitteita, toiveita ja haaveita. Sosiaalipedagogisessa ohjauksessa tutustuminen on aina molemminpuolista, eli myös ohjaaja on läsnä ainutlaatuisena ihmisenä, joka voi kertoa itsestään ja taustastaan, jakaa kokemuksiaan ja ajatuksiaan. Tutustumisen kohteena ovat molemminpuolisesti myös kulttuurit, joita ohjaaja ja opiskelija edustavat.

Tunnustaminen perustuu tutustumiseen. Kyseessä on sellaisten asioiden huomaaminen ja niistä tunnustuksen antaminen, jotka ovat opiskelijalle itselleen merkityksellisiä. Se ei siis ole mahdollista ilman toisen tuntemista ainakin jollain tasolla. Tunnustaa voi sekä sanallisesti, eli esimer- 
kiksi antamalla palautetta onnistumisista tai kysymällä opiskelijan mielipidettä hänelle tärkeästä aiheesta, että toiminnallisesti. Toiminnallista tunnustamista on esimerkiksi vastuutehtävien antaminen, sillä se viestittää opiskelijalle ohjaajan luottamusta. Tulevaisuuteen suuntautuva tunnustaminen eli luottamuksen osoittaminen opiskelijan osaamista ja tavoitteiden toteutumista kohtaan vahvistaa toivon näkökulmaa. Myös tunnustaminen on vastavuoroista, eli ohjaajan on oltava valmis paitsi antamaan myös ottamaan vastaan tunnustusta.

Tukeminen perustuu tutustumiseen ja tunnustamiseen. Jotta ohjaaja voi tukea opiskelijaa hänelle merkityksellisissä asioissa ja merkitykselliseen suuntaan, hänen täytyy tutustua opiskelijaan ja oppia tunnistamaan tälle merkityksellisiä asioita. Sosiaalipedagogisessa ohjauksessa tavoitteena on tukea ensinnäkin osallisuutta. Osallisuus on yhteisöön kuulumista ja mahdollisuuksia osallistua ja vaikuttaa yhteisön jäsenenä. Tällaista osallisuutta opiskeluyhteisössä voi tukea edistämällä jokaisen opiskelijan tunnetta omasta merkityksestään ryhmän jäsenenä ja yhteenkuuluvuuden tunnetta ryhmässä sekä luomalla opiskelijoille mahdollisuuksia olla ryhmän ja oppilaitoksen aktiivisia jäseniä. Osallisuutta yhteiskunnassa puolestaan voi tukea tekemällä yhteiskuntaa, sen toimintatapoja ja -ympäristöjä tutummaksi sekä etsimällä mahdollisuuksia osallistua esimerkiksi vapaaehtoistyön ja kansalaistoiminnan kautta. Toiseksi sosiaalipedagoginen ohjaus pyrkii tukemaan toimijuutta. Toimijuus tarkoittaa mahdollisuuksia tehdä valintoja ja toimia niiden mukaan tietyssä ympäristössä, ja se on jotain, mikä rakentuu suhteessa ympäristöön. Ohjaajan tavoitteena on tukea opiskelijan toimijuutta sekä opinnoissa että elämässä laajemmin. Toimijuus voi kehittyä eri toimintaympäristöissä niin, että se laajenee vähitellen yhteiskunnalliseksi toimijuudeksi. Oleellista on tukea opiskelijan sellaista toimijuutta, joka on hänelle itselleen merkityksellistä. Toimijuuden tukeminen kuitenkin myös pyrkii suuntaamaan toimintaa, eli tavoitteena on vahvistaa sellaista yhteiskunnallista toimijuutta, joka paitsi auttaa ihmistä tulemaan toimeen yhteiskunnan jäsenenä myös mahdollistaa kriittisen osallistumisen yhteiskunnassa.

Sosiaalipedagogisen ohjauksen mallin kolmas osa-alue on työmenetelmät. Ne ovat erilaisia vuorovaikutuksellisia ja toiminnallisia menetelmiä, jotka toimivat apuvälineinä ohjauksen periaatteiden ja prosessin toteuttamisessa. Menetelmiä voi soveltaa ja muokata sen mukaan, millainen työskentely on milloinkin luontevaa ja mielekästä tietyn opiskelijan tai ryhmän kanssa. Menetelmät on jaoteltu kolmeen ryhmään sen perusteella, 
korostuuko niissä prosessin vaiheista tutustuminen, tunnustaminen vai tukeminen. Monet menetelmistä sopivat useampaan vaiheeseen.

Sosiaalipedagogisen ohjauksen mallin laajempi esittely, työmenetelmien kuvaukset, mallia taustoittavia materiaaleja ja muuta lisätietoa löytyy osoitteesta bit.ly/sospevaohjaus. Tämän aikakauskirjan kolme seuraavaa puheenvuorotekstiä perustuvat Sospeva-hankkeen päätösseminaarissa pidettyihin kolmeen loppupuheenvuoroon, joissa hankkeen toteuttajatahojen edustajat arvioivat hankkeen merkitystä omista näkökulmistaan.

\section{LÄHTEET}

Häkli, J., Kallio, K. P. \& Korkiamäki, R. (toim.) 2015. Myönteinen tunnistaminen. Helsinki: Nuorisotutkimusseura.

Korkiamäki, R., Kallio, K. P. \& Häkli, J. 2016. Tunnustaminen näkökulmana ja käytäntönä lapsi- ja nuorisotyössä. Sosiaalipedagoginen aikakauskirja 17, 9-34.

Nivala, E. \& Ryynänen, S. 2019. Sosiaalipedagogiikka. Kohti inhimillisempää yhteiskuntaa. Helsinki: Gaudeamus.

Sosiaalipedagogisen ohjauksen malli 2020. Saatavissa bit.ly/sospevaohjaus (haettu 18.11.2020). 